\title{
A PRELIMINARY STUDY OF VEGETATION ZONES AND WINTER BIRD DISTRIBUTION IN SASKATCHEWAN*
}

WAYNE E. RENAUD, LGL Ltd.- environmental research associates, 4. Eglinton Ave. W., Toronto, Ontario, M4R 1A1, and GUY J. WAPPLE, Box 1153 Biggar, Saskatchewan, SOK OMO.

The distribution of winter birds varies considerably across the 11 degrees (and $1220 \mathrm{~km}$ ) of latitude that encompass present day Saskatchewan. This latitudinal spread includes vegetation zones that range from short-grass prairie through deciduous and coniferous forests, to the sub-arctic transition. Comparative information on bird composition among these vegetation zones in all seasons is sparse. The best information for the early winter period is provided by 946 Christmas Bird Counts conducted from 1940 to 1976.

In an earlier analysis of Christmas counts, bird distribution maps based on geographic units (degree blocks) suggested that the frequency of occurrence of most species was markedly influenced by vegetation zones. $^{56}$ In this paper we use these counts to assess apparent preferences for specific vegetation zones exhibited by the more regular species, and characterize the species composition of each zone.

\section{Methods}

We assigned each count locality to one of the vegetation zones recog-

* Part II of a 35 year review of Christmas Bird Counts in Saskatchewan. Part I appeared in the December 1977 Blue Jay 35:224-239. nized in the Atlas of Saskatchewal (see Figure 1). ${ }^{7}$ In addition to these si: vegetation zones, we have included the Cypress Hills region as a sevent? zone since it has several unique physiographic and vegetationa features. Only one count (Fort Walsh has included extensive mixed wood forest typical of the upper elevation: of the hills. However, counts a Eastend, Maple Creek, Piapot anc Skull Creek are likely under the in fluence of the hills because they in clude streams and their associated riparian habitats that originate in the Cypress Hills; hence, these localitie have been included in the Cypres: Hills region.

We then calculated the frequenc: of occurrence, during count period for each species within each zone (i.e., the percent of total count recording the species). Forty-six com mon species are shown in Figure 2 Given this information, it was possible to obtain an index of species rich ness within each zone (Table 1 ).

The index used is the number 0 species recorded on more than $25 \%$ of the counts. We felt that, with the modest degree of coverage on mos counts, all of these species likel. would be recorded on at least half 0 the counts had the count circles beer covered by larger numbers 0 observers $(20+)$ as in the larger cities 

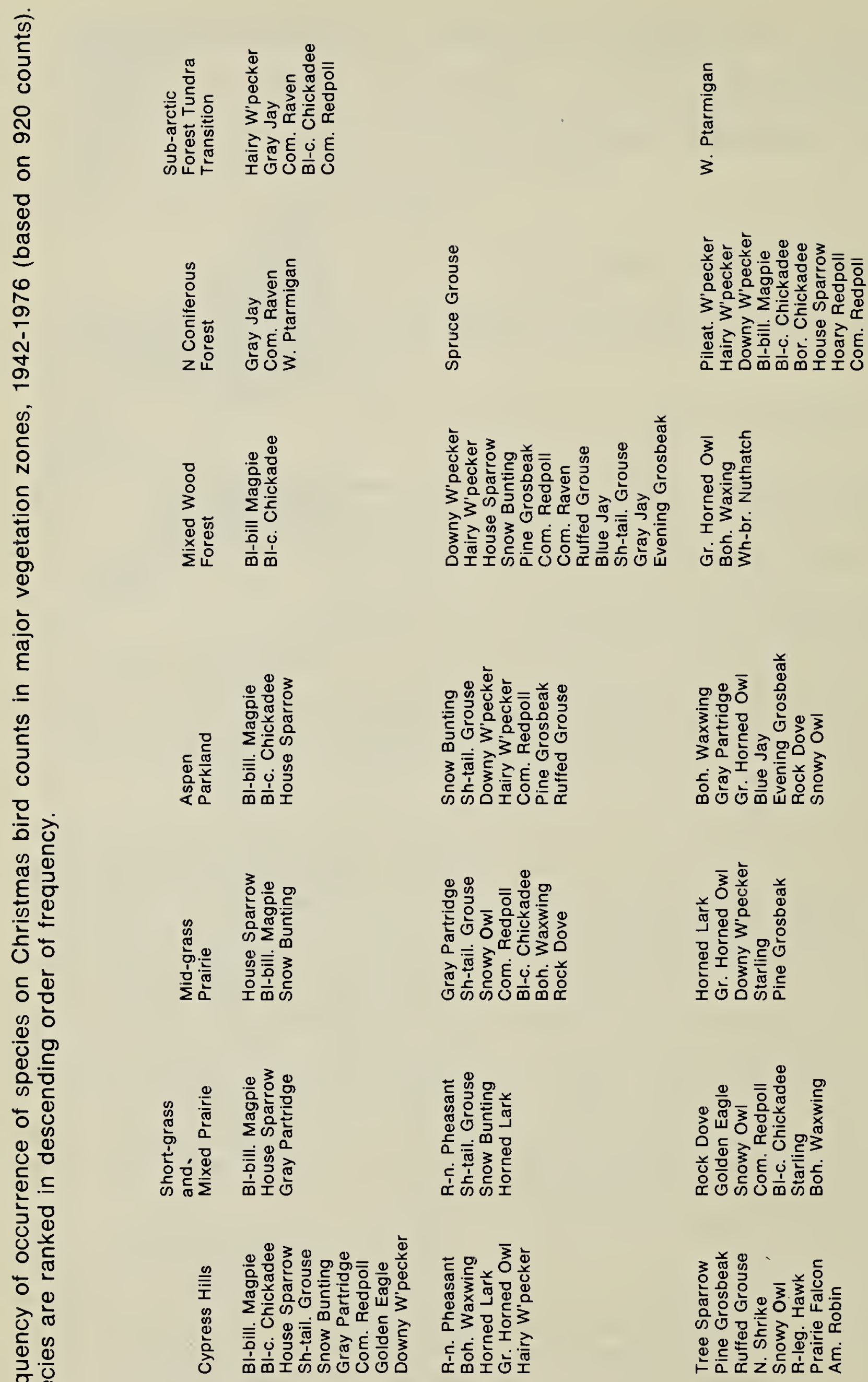
igure 2: Frequency of occurrence of species on Christmas Bird Counts (during count eriod) in seven vegetation zones. The Rock Dove and all species recorded on less than 0 per cent of counts in all vegetation zones are excluded.

VEGETATION ZONE
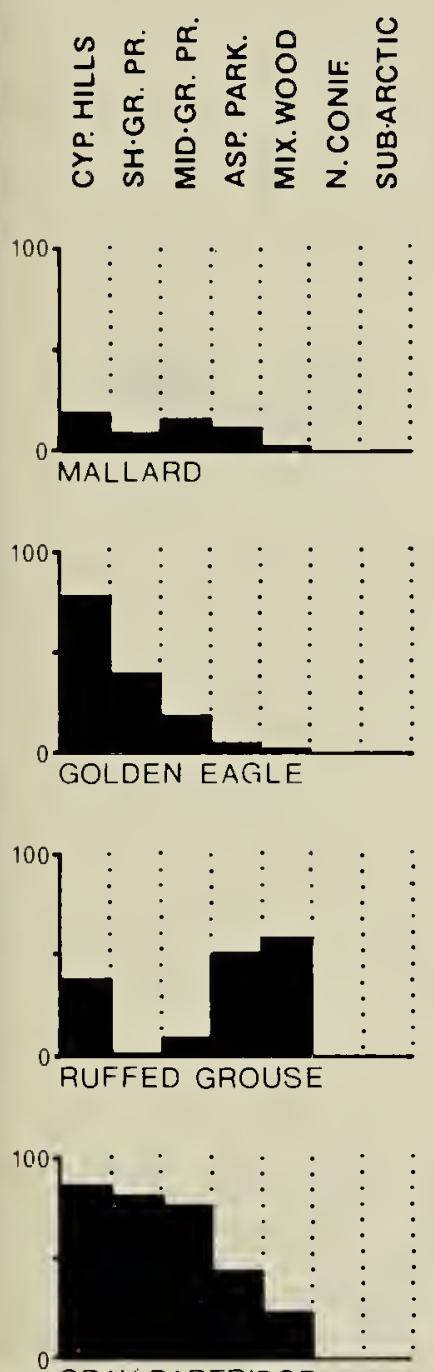

GRAY PARTRIDGE
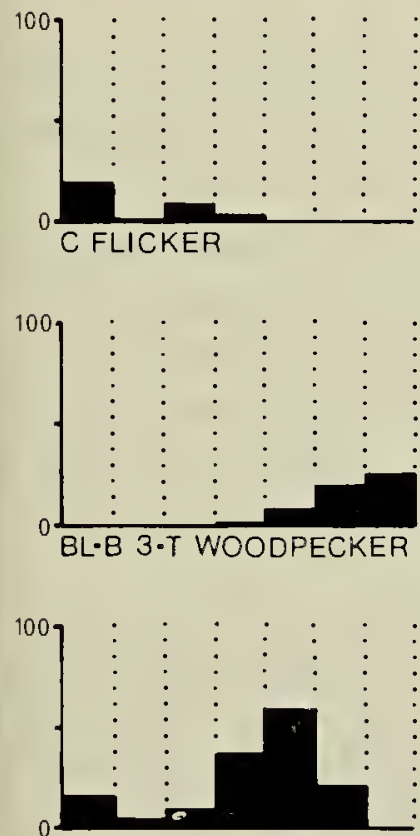

BLUE JAY

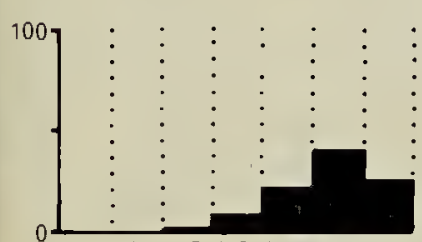

BOREAL CHICKADEE
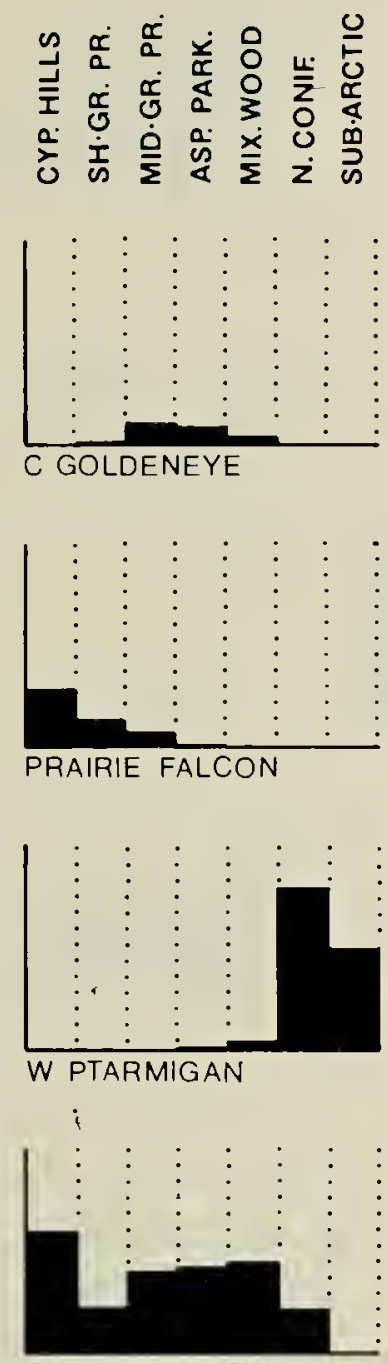

GR HORNED OWL
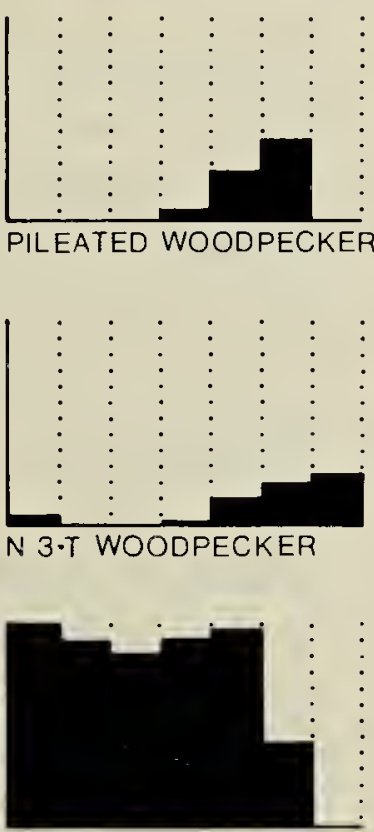

BL·BILL MAGPIE

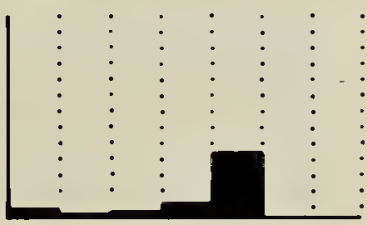

WH:BR NUTHATCH

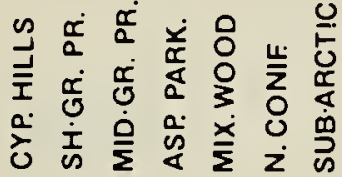

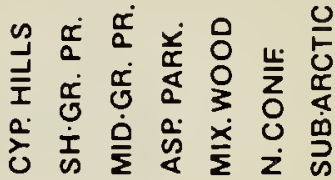
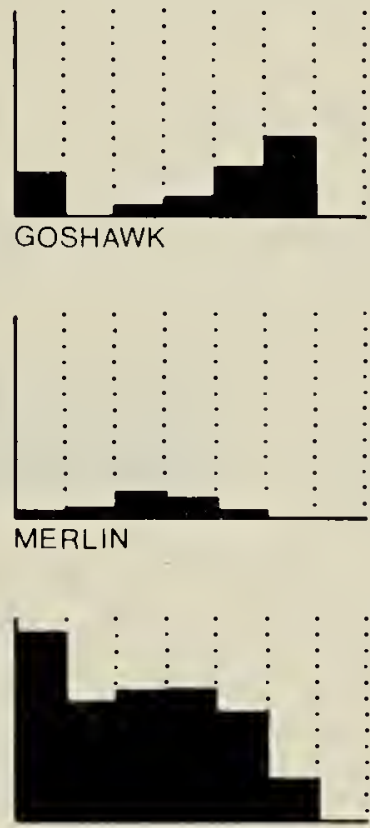

SH·TAIL GROUSE

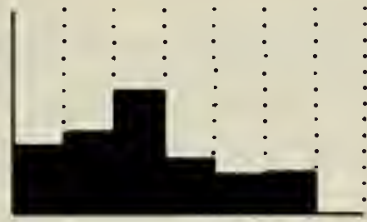

SNOWY OWL

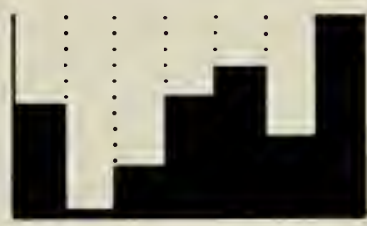

HAIRY WOODPECKER

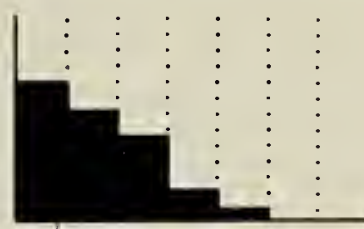

HORNED LARK

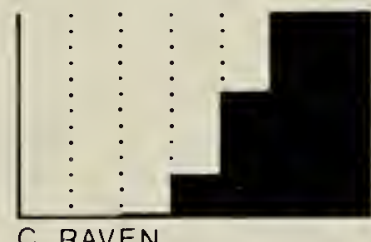

C RAVEN

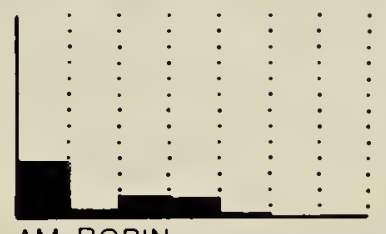

AM ROBIN
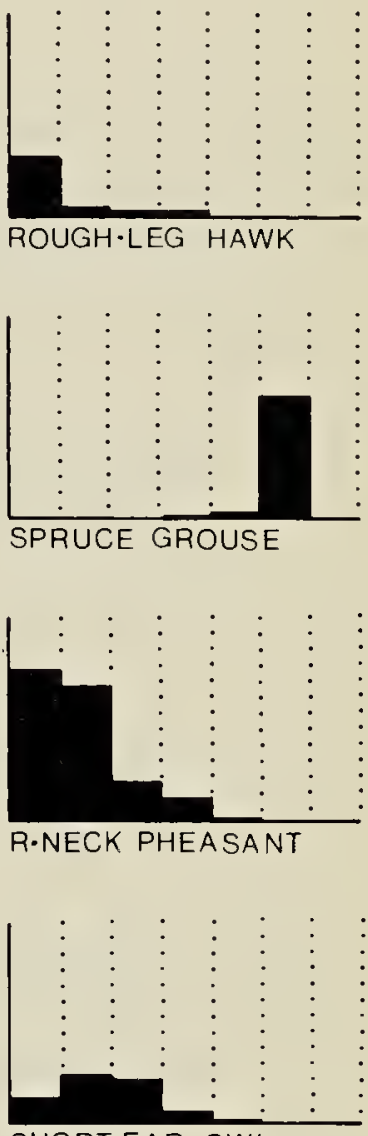

SHORT·EAR OWL

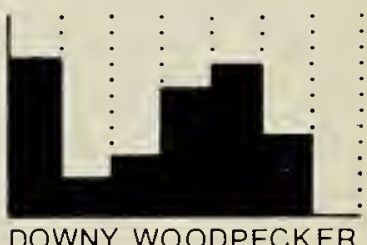

DOWNY WOODPECKER
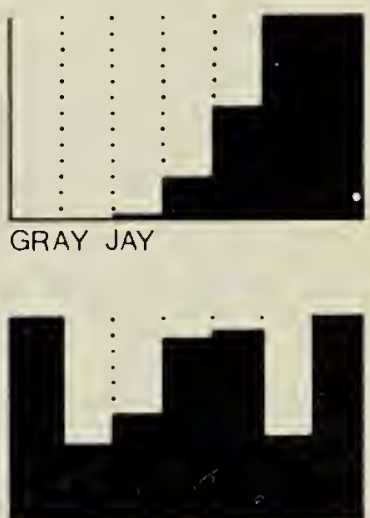

BL-CAP CHICKADEE

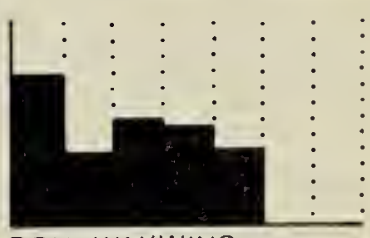



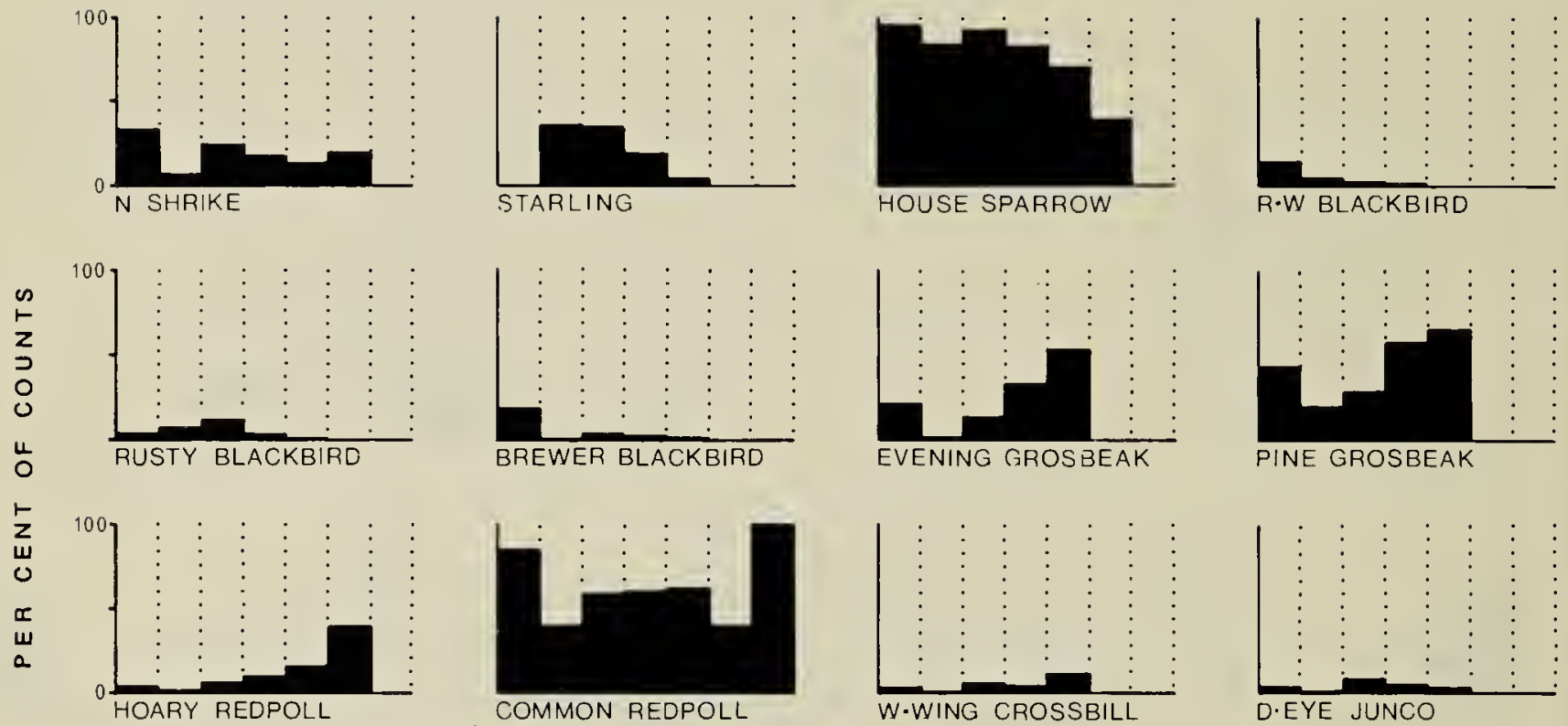

COMMON REDPOLL
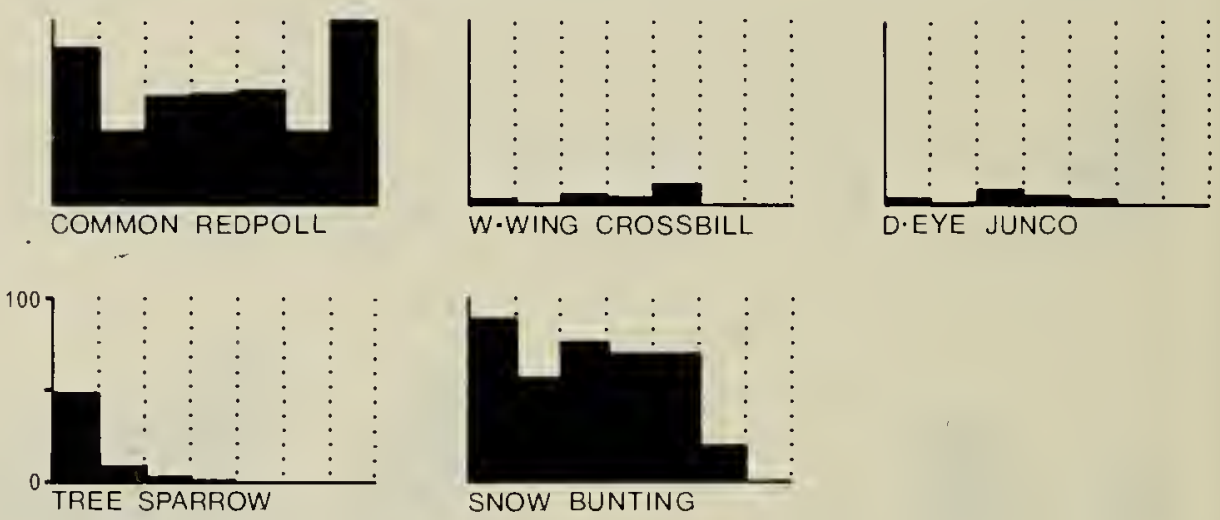

Ten of the 34 species in Table 1 were seen on more than $25 \%$ of the counts in only one vegetation zone. Five of these 10 restricted-distribution species were in the Cypress Hills (Tree Sparrow, Northern Shrike, Rough-legged Hawk, Prairie Falcon, American Robin), four were in the northern coniferous forest (Spruce Grouse, Pileated Woodpecker, Boreal Chickadee, Hoary Redpoll) and one was in the mixed wood forest (Whitebreasted Nuthatch). Only two species, Black-capped Chickadee and Common Redpoll, were included in the index for each of the vegetation zones. The Black-billed Magpie and House Sparrow were indexed in six of the seven zones (not in sub-arctic), and the Hairy Woodpecker was seen in all seven zones but was seen on more than $25 \%$ of the counts in only five zones.

\section{Discussion}

Within the province, the frequency of occurrence of species on Christmas counts differs among vegetation zones. This is probably at least in part a function of the habitat diversity present in each zone. The number of habitats in an area depends upon both the natural environment and the nature and extent of man-induced environmental changes. As long as human activities do not destroy the last examples of any natural habitat, areas modified by human activities would provide a much greater variety of habitat types in which an artificially high degree of species diversity would exist.

In recent years the greatest number of species has been consistently recorded on Christmas Bird Counts in the two largest cities, Regina (located in the mid-grass prairie) and Saskatoon (located on the fringe of the aspen parkland). In the 10-year period, 1967 to 1976, Regina averaged 39 species and Saskatoon averaged 34 species during count period. 
Saskatoon, with a river, and Regina, with a man-made lake, both provided open water during the winter. Open water was a factor explaining the local diversity of birds in these areas. This was especially evident at Regina where a maximum of 19 water-associated species and an average of 12 such species were recorded; at Saskatoon a maximum of 8 and an average of 4 species were recorded.

When water-associated species are excluded from each year's total, Saskatoon averaged 30 species and Regina averaged about 27 species during count period. The total at Saskatoon is similar to some of the higher counts taken by smaller numbers of people in typical areas of the parkland, mixed wood or Cypress Hills vegetation zones. The unexpectedly high total for Regina is perhaps attributable to the large number of observers, compared to other localities in the same vegetation zone, and the relatively great diversity of micro-habitats afforded by an "island" of woodland on the otherwise largely treeless plain.

On a broader scale, one could suggest several obvious reasons for the large number of species recorded on individual counts and the higher species index found in the Cypress Hills, aspen parkland and mixed wood zones. The Cypress Hills and aspen parkland naturally encompass habitats ranging from grassland to forests. The mixed wood component of the Cypress Hills forest provides habitats for additional species not regularly found in aspen parkland. The area is a meeting place for species which have both boreal affinities (e.g., White-winged Crossbill, Goshawk, Northern Three-toed Woodpecker) and montane affinities (e.g., Townsend's Solitaire, Red Crossbill, Gray-crowned Rosy Finch) as well as being a prime wintering area for the more typical prairie species. Most of the boreal and montane species are still infrequently recorded (and hence absent from Table 1); however, as more counts in the Cypress Hills include the extensive mixed wood habitats of the Centre and East Blocks, these species will no doubt become increasingly regular.

The natural diversity of the Cypress Hills and aspen parkland have been further modified by agriculture and other cultural influences. Most counts in the mixed wood zone have been taken along its southern boundary where agricultural practices have resulted in clearing of a part of the forest cover, thus providing openings for species that formerly may have had to travel further south to find suitable winter range (e.g., Snow Bunting). There, as in other more southerly vegetation zones, the presence of farms and towns, with their associated food supplies, have provided yet another micro-habitat which wintering birds have learned to exploit.

Climatic patterns within Saskatchewan probably exert both direct and indirect effects on the number of species that winter in various parts of the province. Climate is an important determinant of the vegetation zones which, in turn, influence species richness. Temperature also affects the distribution of many species through effects on food supplies and energy requirements. With a mean January temperature varying about $22^{\circ} \mathrm{C}$. $\left(40^{\circ} \mathrm{F}\right.$.) latitudinally across the province, ${ }^{7}$ temperature may determine the limits at which a given species is able to balance its energy requirements with the available food resources, taking into account the north-to-south variation in daylight available to diurnal species.

The small number of species 
observed on the prairies is probably the result of the combined effects of low vegetation diversity and exposure. Studies have shown that, even for hardy species like the Snowy Owl and Starling, wind chill significantly increases the energy requirements of the bird. ${ }^{3}$

The wintering bird species of the primeval prairies undoubtedly included fewer species than are present today, since introduced speciesprimarily the House Sprarrow, Gray Partridge and Rock Dove-are now among the most conspicuous winter birds. There is no evidence that any naturally-occurring species have been seriously displaced by introduced species. The growing number of species now occurring locally in southern Saskatchewan (particularly in towns and cities) attest to the new "richness" of these areas.

\section{Summary}

The number of species recorded on more than $25 \%$ of counts in each of the seven vegetation zones (i.e., "species richness") was highest in the Cypress Hills, aspen parkland and mixed wood zones, where a high degree of natural and man-induced habitat diversity now exists. Species richness was lower in the northern coniferous forest, the mid-grass prairie, and the short-grass/mixed prairie. Within the mid-grass prairie and aspen parkland vegetation zones, counts in cities invariably recorded the largest number of species; contributing factors included the availability of open water, a great variety of man-induced habitats (including concentrated natural and artificial food and shelter) and usually more observers.

\section{Acknowledgements}

We wish to thank many persons whose valuable assistance was required for the completion of the first two parts of this 35-year review of Christmas bird counts. Durand Edgett assisted in the initial collating and checking of the information and during the preparation of the distribution maps. Herb Copland, David R.M. Hatch, Larry A. Patterson and C. Eric Tull commented on early drafts of the manuscript. C. Stuart and Mary Houston contributed generously to all aspects of this project. We especially wish to thank Michael S.W. Bradstreet, Kerry J. Finley and W. John Richardson who offered many ideas on methods of analysis and presentation; and J. Bernie Gollop for his exhaustive editorial comments. Lynn Wright, Irene Reinson and Heather Craig typed several drafts of the manuscript. The technical support provided by LGL Ltd.environmental research associates is greatly appreciated.

'GESSAMAN, J.A. 1972. Bioenergetics of the Snowy Owl (Nyctea scandiaca). Arctic and Alpine Research 4:223238.

${ }^{2} \mathrm{HOHN}$, E.O. 1977. Winter bird observations at Uranium City, Saskatchewan. 1969-1976. Blue Jay 35:3132.

${ }^{3}$ KELTY, M.P. and S.L. LUSTICK. 1977. Energetics of the Starling (Sturnus vulgaris) in a pine woods. Ecology 58:1181-1185.

${ }^{4}$ NERO, R.W. 1963 . Birds of the Lake Athabasca region, Saskatchewan. Spec. Publ. No. 5, Sask. Nat. Hist. Soc. 143 pp.

${ }^{5}$ RENAUD, W.E. and G.J. WAPPLE. 1977. A review of Saskatchewan Christmas Bird Counts: 1942-1976 (Part I). Blue Jay 35:224-239.

RENAUD, W.E. and G.J. WAPPLE. 1978. Errata and addenda. A Review of Saskatchewan Christmas Bird Counts: 1942-1976 (Part I). Blue Jay 36:121.

${ }^{7}$ RICHARDS, J.H. and K.I. FUNG. 1969. Atlas of Saskatchewan. University of Saskatchewan. Saskatoon. 236 pp. 